\title{
Construction and preliminary evidence of validity of the Scale of Perceived Threat from the Mentally III
}

\author{
Elaboração e evidências preliminares de validade da Escala \\ de Percepção de Ameaça frente ao Doente Mental
}

\author{
Silvana Carneiro MACIEL'1 (D) 0000-0003-1489-1126 \\ Luana Elayne Cunha de SOUZA² ID) 0000-0001-9425-9598 \\ Tiago Jessé Souza de LIMA3 ID 0000-0001-8840-4285 \\ Patrícia Fonseca de SOUSA ${ }^{1}$ ID 0000-0003-1885-2626 \\ Cícero Roberto PEREIRA ${ }^{1}$ ID 0000-0003-3406-3985
}

\begin{abstract}
The perception that mental patients represent a threat may support attitudes and behaviours of social exclusion and a contrary position to the precepts of the Psychiatric Reform. In this sense, this article has the objective of elaborating the Scale of Perceived Threat from the Mentally III and reporting the preliminary evidences of its factorial validity and internal consistence. For this purpose, two studies were performed: Study 1 performed an exploratory factor analysis composed of 244 university students aged 17 to 56 years old $(M=22.98$; SD = 5.61); and study 2 performed a confirmation factor analysis from a sample of 247 university students aged between 17 and 51 years old $(M=23.08 ; S D=5.75)$. The final scale was composed of nine items grouped into two factors: dangerousness and unpredictability, and presented good psychometric properties, being able to be used adequately to evaluate the perception of threat regarding the mentally Ill.
\end{abstract}

Keywords: Mental disorders; Prejudice; Scale.

1 Universidade Federal da Paraíba, Centro de Ciências Humanas, Letras e Artes, Programa de Pós-Graduação em Psicologia Social. Campus I, Cidade Universitária, Castelo Branco, 58059-900, João Pessoa, PB, Brasil. Correspondence to: S.C. MACIEL. E-mail: <silcamaciel@gmail.com>.

2 Universidade de Fortaleza, Departamento de Psicologia, Programa de Pós-Graduação em Psicologia. Fortaleza, CE, Brasil.

3 Universidade de Brasília, Departamento de Psicologia Social e do Trabalho, Programa de Pós-Graduação em Psicologia Social, do Trabalho e das Organizações. Brasília, DF, Brasil.

Support: Coordenação de Aperfeiçoamento de Pessoal de Nível Superior (Protocol no 01/2016).

$\boldsymbol{\nabla} \boldsymbol{\nabla} \boldsymbol{\nabla}$

How to cite this article

Maciel, S. C., Souza, L. E. C., Lima, T, J. S., Sousa, P. F., \& Pereira, C. R. (2020). Construction and preliminary evidence of validity of the Scale of Perceived Threat from the Mentally Ill. Estudos de Psicologia (Campinas), 37, e190135. https://doi.org/10.1590/1982-0 275202037 e190135 


\section{Resumo}

A percepção de que pessoas com transtornos mentais representam uma ameaça pode embasar atitudes e comportamentos de exclusão social e um posicionamento contrário aos preceitos da Reforma Psiquiátrica. Nesse sentido, este artigo teve como objetivo reportar a elaboração da Escala de Percepção de Ameaça frente ao Doente Mental e as evidências preliminares de sua validade fatorial e consistência interna. Para tanto, foram realizados dois estudos: no Estudo 1, efetuou-se uma análise exploratória em uma amostra composta por 244 estudantes universitários com idades variando entre 17 e 56 anos $(M=22,98 ; D P=5,61)$; e, no Estudo 2, procedeu-se a uma análise confirmatória em uma amostra de 247 estudantes universitários com idades variando entre 17 e 51 anos $(M=23,08 ; D P=5,75)$. A escala final ficou constituída de nove itens agrupados em dois fatores - periculosidade e imprevisibilidade -, com boas propriedades psicométricas, podendo ser adequadamente utilizada para avaliar a percepção de ameaça frente ao doente mental.

Palavras-chave: Transtornos mentais; Escala; Preconceito.

The history of mental disorders has always been guided by different elements and terms such as "user" of substitute health services, "patient", "crazy", among others, influencing cultures, values and beliefs, and demonstrating the various ways that societies represent and behave towards people with mental disorders. There are many adopted terms, attitudes and beliefs; each term has a different social meaning, producing and reproducing ideological representations through its impact on collective experiences. However, to the detriment of the term that is used and scientific and temporal advancement, stereotypes and prejudice remain; in regards to this, Rosa (2003) emphasizes that all terms are loaded with prejudice and always indicate a deviation from the norm and social acceptance.

Over time society has sought parameters for determining the criteria of "normal" and "abnormal", which remains today on the agenda as one of the central issues of the problem of mental disorders and living in society. Several explanations have already been given, including religious ones, linked to evil spirits, those connected to organic factors and, more recently, explanations related to psychological and social issues. Despite these developments, people with mental disorders have been treated, medicalized, labeled and excluded from society, a fact explained by Foucault (1960/2012), who emphasized that mental disorders are the object of a discourse that describes a complex social image, linked to prejudice and social exclusion.

Currently, important transformations are happening in the field of mental health with the advent of the Psychiatric Reform, implying theoretical-conceptual, technical-assistance, juridical-political and cultural changes (Shimoguiri \& Costa-Rosa, 2017); however, prejudiced ideas created during the asylum period are still present in our society. Thus, negative attitudes and behavior towards people with mental disorders are still part of today's society (Amorim \& Lavrador, 2017; Schlier, Schmick, \& Lincoln, 2014), in that they impact the lives of these people who are prevented from exercising autonomy over their lives, finding employment and exercising their basic rights, as attested by Pescosolido, Medina, Martin, and Long (2013).

Several authors point out that representations are maintained that it is dangerous to live with people with mental disorders, because they are perceived as people who cause fear, who can act aggressively at any time and who represent a threat to the physical and social integrity of the community (Angermeyer, Matschinger, Carta, \& Schomerus, 2014; Evans-Lacko, Henderson, \& Thornicroft, 2013; Jodelet, 2005; Serafim, Bú, Maciel, Santiago, \& Alexandre, 2017). These ideas reflect on the establishment of relationships with people in psychological distress, marked by prejudice and social exclusion, supported by the perception that this group represents a threat, bringing as a consequence the desire for social distance and the confinement of these individuals, which constitutes an obstacle to the functional possibilities of recovery (Sousa, Marques, Curral, \& Queirós, 2012).

For Fukuda, Penso, Amparo, Almeida, and Morais (2016), the negative social image of these people still remains due to the historical aspects of representations that have been propagated over time, associated with 
the lack of information from the population and the ineffectiveness of public policies of social inclusion. Such representations serve as justifications for the notions of prejudice and social exclusion for these individuals, even in societies where the discourse of valuing social inclusion and the defense of human rights is promoted.

In order to understand how this phenomenon occurs, Pereira and Vala (2011) propose the Justified Discrimination Model, highlighting that in the face of anti-prejudice rules, people resort to argumentative strategies to allow discriminatory action without being seen as "politically incorrect". According to the authors, people exclude by legitimizing their discriminatory behavior with arguments that are apparently not prejudiced, so that their behavior, even when excluding, is perceived as fair, legitimate and necessary (Pereira \& Souza, 2016; Pereira, Vala, \& Leyens, 2009; Pereira, Vala, \& Costa-Lopes, 2010; Pereira \& Vala, 2011). One of the main factors that people commonly resort to, so as to justify their need for differentiation of social minorities, is the perception that these minorities pose a threat to the survival of the group belonging to these people.

In fact, this threat has received special attention in the study of prejudice and discrimination of different social groups (Monterrubio, 2015). In this regard, Stephan and Stephan (2000) proposed the Integrated Threat Theory, which considers that prejudice against social groups is based on four dimensions: "the perception of a realistic threat", which refers to the threat to economic power or physical well-being; "the perception of symbolic threat", which corresponds to the perceived differences between the groups in values, beliefs and norms; "negative stereotypes", which generate negative expectations for interaction; and "intergroup anxiety", which is the anxiety generated by the possibility of establishing contact with members of other groups. Specifically, Barros, Torres, and Pereira (2017) state that the relationship between perception of threat and discrimination stems from the feeling of threat as a motivating factor for discrimination. This is because, in an attempt to defend the interests of the ingroup, the perceived threat represents the feeling that the outgroup may decrease the well-being of the ingroupand this serves as a justification for the emergence of hostile attitudes towards members of the group who are perceived as the source of the threat.

It should be noted that, in the context of the relationship between society and people with mental disorders, it makes sense to understand the feeling of threat that is linked to the need to defend the physical integrity of the in group (in this case people who do not have mental disorders) from the outgroup (people with mental disorders). This occurs because the stereotyped representations and beliefs shared in society anchored in the perception of the threat to the population from this social group serve as a justification for the prejudice and social exclusion of people with mental disorders (Neto \& Avellar, 2015). According to Jodelet (2005), attempts at social reintegration of "deinstitutionalized" patients reveal that communities show great resistance associated with the idea of dangerousness and an increasing tendency to avoid contact with these individuals. In this sense, it can be said that the perception of threat from people with mental disorders can lead to discrimination, which in turn is reflected in behaviors of social exclusion, anchored in the rejection of the Psychiatric Reform, which proposes, as stated by Simoni, Lazarini, and Madureira (2017), the deinstitutionalization and social inclusion of these people into society.

Therefore, identifying the perception of threat from people with mental disorders becomes essential in this context of consolidation of the Psychiatric Reform, as this construct works as a justification of prejudice (Pereira et al., 2010; Pereira, Alvaro, \& Vala, 2018), directly impacting the population's support for the proposal of social inclusion of people with mental disorders in the family and society, mainly due to the new mental health policies in force in Brazil and in the world, advocating deinstitutionalization and social inclusion.

Considering the importance of examining more carefully this issue and knowing a little more about the research developed in the area of perceived threat from people with mental disorders, searches were made in the second half of 2018 in Google Scholar and in the databases Index Psi, MedLine, PubMed, PsycINFO, and Scopus data, using "scale", "threat perception", "mental disorder" and "mental illness" as descriptors. From these searches, no specific measures of the perception of threat from people with mental disorders were 
identified in the Brazilian context, a fact that makes the proposal of this measure even more relevant, and which may contribute to overcome a gap of measures of this construct, especially in the Brazilian context. However, it is known that the proposition of an instrument to measure a psychological construct is not simple, because in addition to the need for a good theoretical basis that fundamentally justifies it, there is still the need to observe all the necessary procedures for its elaboration and validation, as well as the procedures for administration and correction, as highlighted by Reppold, Gurgel, and Hutz (2014). In this sense, this article aims to construct and demonstrate preliminary evidence of factorial validity and internal consistency of the Scale of Perceived Threat from the Mentally III (SPTMI).

With regard to validity, Pacico, Hutz, Schneider, and Bandeira (2018) state that the concept of validity has been used with different meanings for several attempts throughout history to standardize and formalize the concept and validation procedures, while also highlighting that establishing the validity of a test requires relevant evidence that provides a secure scientific basis for the interpretation of results. The authors point out that the new version of the Standards for Educational and Psychological Testing (American Educational Research Association [AERA], American Psychological Association [APA], \& National Council on Measurement in Education [NCME], 2014, p.56) states that "the sources of evidence of validity can be based on: (1) the content of the test; (2) the response process; (3) the internal structure; (4) relationships with other variables and (5) the consequences of testing". However, each source of evidence of validity should shed light on different aspects of validity, but this does not represent different types of validity, as this is a unitary concept, being defined as the degree to which all the accumulated evidence supports the interpretation of the scores of a test for the intended use.

This article aims to elaborate and demonstrate preliminary evidence of factor validity and internal consistency of a scale, taking into account the literature that exists in the area and the compliance of the evaluated construct (perceived threat) obtained through the analysis of covariance structures between the test parts, namely: factor analysis, internal consistency analysis and structural equation modeling; and to find the best indexes, indicators proposed in the literature were used (Garson, 2012; Horn, 1965). The methodological trajectory and forms of analysis will be explained below.

\section{Study 1. Construction of the Scale of Perceived Threat from the Mentally III (SPTMI)}

Study 1 aimed to describe the construction of the scale proposed herein and provide initial evidence of factorial validity and internal consistency of the measure.

\section{Method}

\section{Participants}

Take part in this study 244 university students participated with ages varying between 18 and 56 years old $(M=22.98 ; S D=5.61)$, the majority being female $(79.7 \%)$, the students were distributed among Psychology (22.1\%), Social Work (16.8\%), Occupational Therapy (18.9\%), Nursing (22.5\%) and Medicine $(19.7 \%)$ courses. Inclusion criteria were established, these were: being over 18 years old and belonging to courses that work with the themes of mental health, and that these courses are linked to the professional areas inserted into the services of the health care network, and that serve people with mental disorders, and that the students are likely future professionals in the field, taking their beliefs and representations to the field of professional practice.In regard to contact with people with mental disorders, $20.9 \%$ of the participants 
declared that they lived with one in the family, of which $92.2 \%$ live in the same house and only $5.9 \%$ in hospitals. When asked if the person with a mental disorder with whom they live is aggressive, $23.5 \%$ said yes. Subsequently, we asked them to indicate on a scale from 0 to 10 how aggressive this individual is and the average response was $2.16(S D=1.99)$.

\section{Instrument}

Initially, a bank of items related to the perception of threat from the mentally Ill was elaborated based on phrases extracted from interviews conducted in a previous study (Maciel, Pereira, Lima, \& Souza, 2015) with mental health professionals, with relatives of hospitalized people with mental disorders, from a focus group of 10 psychology students with the theme of people with mental disorders and social inclusion, and from existing banks of the Research Group on Mental Health and Chemical Dependency, coordinated by the first author of this work and of the theoretical framework on the theme (Maciel et al., 2015). The items were elaborated from an analysis of the content of the interviews and of the material collected in the focus group, using Bardin's Thematic Content Analysis (Bardin, 2002).

After elaborating the items, they were submitted to the analysis of 5 judges specialized in the study of mental disorders (Master's and Doctors) to assess the coherence between the definition of the latent trait (dimension) and the behaviors (items) that would be represented empirically. A minimum criterion of $80 \%$ agreement was adopted between the judges, indicating whether the item was relevant to the latent trait, measuring what was theoretically proposed. The objective was to verify the relevance of the contents to describe the perceived threat construct. After the analysis of the questions and guidelines for adjustments, 10 items were retained. As an example of items, we have: "It is very dangerous to live with a mental patient", "Mental patients can act aggressively at any time". Participants responded to each item using a five-point Likert Scale, ranging from "strongly disagree" (1) to "strongly agree" (5). In addition to the scale, the participants answered the sociodemographic questionnaire containing questions about age, sex and contact with the person with mental disorder.

\section{Procedure}

The instrument was applied in the classroom and answered individually. All subjects were informed of the voluntary nature of their participation in the research, the guarantee of anonymity of the answers given and respect for the ethical guidelines that govern research with human beings. The project was approved by the Research Ethics Council of the Federal University of Paraiba (protocol $n^{\circ}$ 138515), in accordance with Resolution 466/2012 and all ethical care involving research with human beings was safeguarded, in accordance with Resolution 510/16 of the National Health Council.

\section{Data analysis}

Exploratory Factor Analysis and internal consistency of the measurement were performed using the IBM ${ }^{\circledR}$ SPSS ${ }^{\circledR}$ Software (version 21). The method of principal axis was adopted in order to know the dimensionality of the scale. We choose this method because it is specific for the analysis of latent factors, such as the perception of threat. In regard to criteria for the extraction of the factors, the eigenvalue equal to or greater than 1 (Kaiser criterion) (Damásio, 2012), the parallel analysis (Horn, 1965), and the interpretability of the extracted factors (Garson, 2012) were adopted. The method of rotation used was the obliging, where we specify that in the oblique rotation the different factors emerging from the perceived threat are correlated. 
The cutoff point for the factorial load was 0.40 (Matsunaga, 2010). In the case of an item obtaining high factorial loads in one or more factors, it was decided to retain the item in the factor in which it presented the greatest load. To assess the internal consistency of the measure, Cronbach's alpha was used, considering values above 0.70 to be adequate (Nunnally, 1991), and the homogeneity index (mean inter-item correlation), assuming as adequate values equal to or greater than 0.20 (Clark \& Watson, 1995).

\section{Results}

First, we conducted an analysis of the adequacy of the correlation matrix for carrying out a factor analysis. A Kaiser-Meyer-Olkin of 0.85 and a significant Bartlett sphericity test, $\chi^{2}(45)=820.33, p<0.001$, were obtained, which indicate that this matrix is suitable for factoring. In the first analysis, without determining the number of factors to be extracted, 3 factors were obtained with eigenvalues greater than 1. However, the parallel analysis indicated that only the first two factors were adequate, as they presented values above those obtained at random. Thus, it was decided to perform a new analysis fixing the extraction of 2 factors. The factorial solution, the items and their respective factor loads, as well as the internal consistency indicators are shown in Table 1.

Table 1

Exploratory factorial analysis of Scale of Perceived Threat from the Mentally III

\begin{tabular}{|c|c|c|c|}
\hline \multirow{2}{*}{ Items } & \multicolumn{2}{|c|}{ Factors } & \multirow{2}{*}{$h^{2}$} \\
\hline & Factor 1 & Factor 2 & \\
\hline 2. It is frightening to think of people with mental illness living in residential neighborhoods. & 0.80 & -0.17 & 0.52 \\
\hline 3. Mentally IIl people are dangerous people. & 0.74 & 0.07 & 0.60 \\
\hline 8. Mentally III people threaten the tranquility of a neighborhood. & 0.62 & 0.01 & 0.40 \\
\hline 1. It is very dangerous to live with a mental patient. & 0.58 & 0.17 & 0.47 \\
\hline 4. I feel some fear when I am in the presence of the mentally III. & 0.55 & 0.08 & 0.36 \\
\hline 7. Mentally IIl people are unable to feel pity. & 0.38 & 0.26 & 0.32 \\
\hline 9. Mentally IIl people have a lot of physical strength. & -0.10 & 0.64 & 0.35 \\
\hline 6. Mentally IIl people are people who can kill easily. & 0.24 & 0.62 & 0.60 \\
\hline 10. Mentally IIl people have perverted sexuality. & 0.03 & 0.61 & 0.40 \\
\hline 5. Mental patients can act aggressively at any time. & 0.14 & 0.59 & 0.46 \\
\hline Explainedvariance (\%) & 42.75 & 12.97 & \\
\hline Cronbach's Alpha & 0.80 & 0.75 & \\
\hline Inter-item Correlation & 0.45 & 0.43 & \\
\hline
\end{tabular}

Note: Bold numbers indicate the items retained for each factor. Fator 1 called dangerousness; Factor 2 called Unpredictability.

The final solution retained 9 of the 10 items proposed, since item 7 was excluded because it had a factorial load below the previously established cut-off criterion (0.40). The perceived threat scale was bifactorial, with the factors named as dangerousness and unpredictability, based on the semantic content of the items and corroborating with research in the areas that demonstrate that the greatest predictors of prejudice against people with mental disorders are supported by the stereotypes of dangerousness and unpredictability associated with the attribution of responsibility (Angermeyer et al., 2014; Loureiro, Dias \& Aragão, 2008). The correlation between the factors is average $(r=0.52, p<0.001)$, which ensures that the oblique rotation was the most appropriate for the interpretation of these factors.

Factor 1, called dangerousness, retained items 1, 2, 3, 4 and 8. Its eigenvalue was 4.27, explaining $42.75 \%$ of the total variance. This first factor presented Cronbach's alpha of 0.80 and a homogeneity index

6 (mean inter-item correlation) of 0.45 . The items of this factor are related to the fear of living with the person 
with mental disorder because they are seen as dangerous and aggressive. Factor 2, called Unpredictability, retained items 5, 6, 9 and 10. Its eigenvalue was 1.29, explaining $12.97 \%$ of the total variance. This second factor presented Cronbach's alpha of 0.75 and a homogeneity index (mean inter-item correlation) of 0.43 . This factor is anchored in behavioral stereotypes of impulsivity/unpredictability linked to physical strength and perverted sexuality.

\section{Discussion}

The objective of this study was to elaborate the SPTMI and demonstrate evidence of factor validity and internal consistency of this instrument. The scale was composed of nine items, distributed into two dimensions, both factors gathered preliminary evidence of factorial validity and good indicators of internal consistency.

The scale measures the perception of threat, which consists of two factors based on negative stereotypes about the person with mental illness: dangerousness and unpredictability. The first factor brought together items that address the perception of danger, the idea that the person with the mental disorder is essentially someone dangerous and can cause some physical damage, i.e., the idea that they are eminently dangerous and aggressive individuals. The second factor, unpredictability, portrays the idea that mental patients are unpredictable people, who cannot be trusted, with issues such as impulsiveness and lack of control, which are linked to issues of behavioral changes, anchored in the lack of impulse control.

Thus, the perception of threat is anchored in issues related to dangerousness and unpredictability in people with mental disorders, supported by behavioral issues linked to the fear that the ingroup will be reached by the outgroup in their physical integrity (Melo, 2017), thus corroborating with Stephan and Stephan's Integrated Threat Theory (2000) in the dimensions of perceived realistic threat, especially in regard to the physical well-being of the ingroup, and in the negative stereotypes dimension, which generates negative expectations of interaction with members of the outgroup. In this regard, Barros et al. (2017) state that the perception of the outgroup as a source of threat in terms of decreasing the well-being of the ingroup generates hostile attitudes and behaviors towards the outgroup causing the perception of threat. In the case of this study, the outgroup is represented by people with mental disorders.

In view of these findings and seeking to gather additional evidence of factor validity and internal consistency of the scale and in order to confirm the presented factorial structure, it was decided to conduct a new study using confirmatory factor analysis. This procedure is especially important for making more robust decisions about the factorial structure of the measurement because it allows for the comparison of the proposed model with alternative hypotheses about the relationships between the items on the scale.

\section{Study 2. Confirmatory Analysis of the Scale for Perceived Threat from the Mentally III (SPTMI)}

The objective of this study is to gather additional evidence of factorial validity and accuracy of SPTMI, through a confirmatory factor analysis. The two-factor model identified in Study 1 was tested, comparing it with three alternative models.

\section{Method}

Participants

Participated 247 university students in this study, with ages varying between 18 and 51 years $(M=23.08$; $S D=5.75)$, the majority being female $(72.8 \%)$, the students were distributed among Psychology (17.8\%), 
Social Work (23.9\%), Occupational Therapy (21.9\%), Nursing (18.2\%) and Medicine (18.2\%) courses, following the same inclusion criteria of Study 1. As for the contact with people with mental disorders, $27.2 \%$ of the participants declared that they lived with one in the family, of which $98.5 \%$ live in the same house and only $1.5 \%$ in hospitals. When asked if the person with mental disorder with whom they live is aggressive, $15.4 \%$ said yes. In addition, on a scale of 0 to 10 , the mean aggressiveness of these individuals was $2.27(S D=2.24)$.

\section{Instrument}

The final version of the SPTMI consisted of 9 items that assess two dimensions, namely: "dangerousness" (e.g., Mentally IIl people are dangerous people) and "unpredictability" (e.g., Mentally Ill people can act aggressively at any time), being answered on a scale of five points, which ranges from 1 (strongly disagree) to 5 (strongly agree).

\section{Procedure}

For data collection, the same procedures described in Study 1 were followed.

\section{Data analysis}

In order to gather additional evidence of the factorial validity of the measurement, the Analysis of Moment Structures (AMOS) 18.0 was used to perform confirmatory factor analyzes, taking into account the covariance matrix and adopting the Maximum Likelihood estimator. The missing data make up 2.02\% of the observations and for this reason were replaced by the mean of the responses obtained in each item. To know the fit of the proposed model and to compare it with alternative models, the following indicators were used: the chi-square ratio by degrees of freedom $\left(\chi^{2} / \mathrm{gl}\right)$, where values in the range of 2 to 3 indicate an appropriate fit, admitting up to 5 (Byrne, 2010); the Goodness of Fit Index, the Adjusted Goodness of Fit Index and the Comparative Fit Index, where values equal to or greater than 0.90 indicate a good fit; and the Root Mean Square Error of Approximation, where values of 0.06 or less indicate satisfactory adjustment, accepting those up to 0.10 (Byrne, 2010). In addition, the chi-square difference $\left(\Delta \chi^{2}\right)$ and the Expected Cross-Validation Index (ECVI) were used to evaluate improvements between the competing models tested. Significant $\Delta \chi^{2}$ values and lower ECVI values reflect a model with a better fit. The first indicator is used to compare nested models and the second is useful for comparing non-nested models (Garson, 2012).

\section{Results}

Initially, a confirmatory factor analysis was performed, testing the model with two correlated factors as proposed in Study 1. The indicators for this model ensure its empirical adequacy, as can be seen in Table 2. Furthermore, to ensure the relevance of this model, it was decided to compare it with alternative models. Specifically, the proposed model (Model 1 - two correlated factors) was compared with three alternative models: Model 2 (two uncorrelated factors); Model 3 (two factors being predicted by a second order factor); and Model 4 (unifactorial). The adjustment indices for the four models tested are shown in Table 2.

Observing the results for the four models presented in Table 2, it can be seen that Model 1, originally proposed, presents the best adjustment indicators in comparison to Models 2, 3 and 4 . Furthermore, both the ECVI values and the difference between the chi-square values $\left(\Delta \chi^{2}\right)$ indicate that the proposed model is 
Table 2

Adjustment indexes for the tested alternative models

\begin{tabular}{lccccccccccc}
\hline Models & $\chi^{2}$ & $(\mathrm{gl})$ & $\chi^{2} / \mathrm{gl}$ & $\mathrm{GFI}$ & $\mathrm{AGFI}$ & $\mathrm{CFI}$ & RMSEA & $(\mathrm{IC}-90 \%)$ & $\mathrm{ECVI}$ & $\Delta \chi^{2}$ & $(\Delta \mathrm{gl})$ \\
\hline Model 1 & 84.34 & $(26)$ & 3.24 & 0.93 & 0.88 & 0.92 & 0.096 & $(0.073-0.119)$ & 0.50 & & \\
Model 2 & 193.74 & $(27)$ & 7.18 & 0.87 & 0.78 & 0.77 & 0.158 & $(0.138-0.180)$ & 0.93 & $109.40^{*}$ & $(1)$ \\
Model 3 & 130.92 & $(27)$ & 4.85 & 0.89 & 0.81 & 0.85 & 0.125 & $(0.104-0.147)$ & 0.68 & $46.58^{*}$ & $(1)$ \\
Model 4 & 130.92 & $(27)$ & 4.85 & 0.89 & 0.81 & 0.85 & 0.125 & $(0.104-0.147)$ & 0.68 & $46.58^{*}$ & $(1)$ \\
\hline
\end{tabular}

Note: Model 1: Two correlated factors; Model 2: Two unrelated factors; Model 3: Two factors being predicted by a second order factor; Model 4: unifactorial. ${ }^{*} p<0.01$.

AGFI: Adjusted Goodness of Fit Index; CFI: Comparative Fit Index; ECVI: Expected Cross-Validation Index; GFI: Goodness of Fit Index; RMSEA: Root Mean Square Error of Approximation.

the one that best fits the data. Therefore, these results ensure that the model with two correlated factors adequately assesses the perception of threat to mentally III. In this case, all $\lambda$ were greater than 0.30 , being statistically different from zero $(\lambda \neq 0 ; z>1.96, p<0.05)$. Figure 1 shows the factorial structure of this model. Regarding the internal consistency indexes, Cronbach's alpha $(\alpha)$ and homogeneity (mean inter-item correlation, $\left.r_{m . i}\right)$, were computed for each factor, with the following values being observed: Dangerousness $\left(\alpha=0.79, r_{m . i}=0.44\right)$ and Unpredictability $\left(\alpha=0.74, r_{m . i}=0.42\right)$.

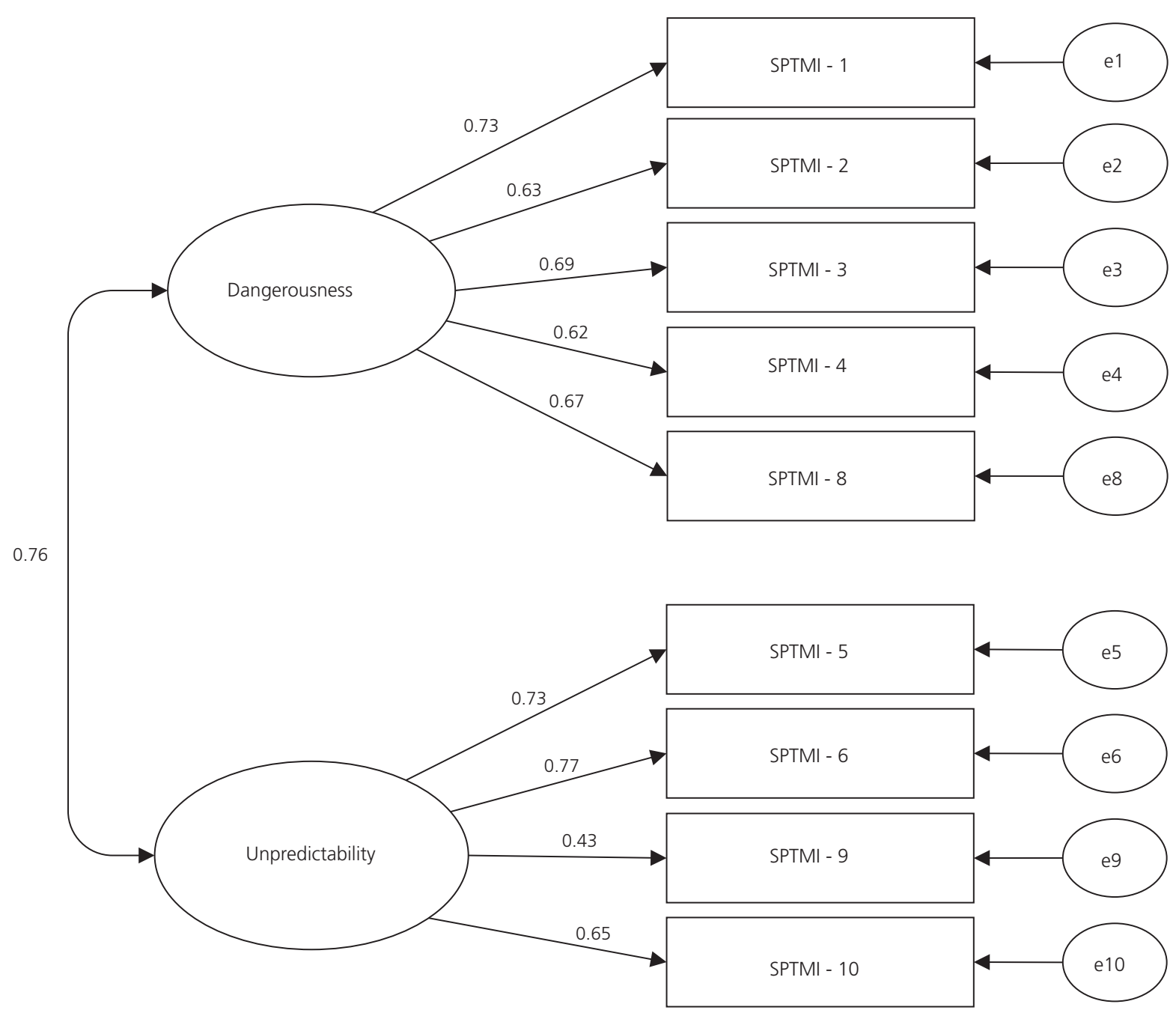

Figure 1. Factor structure of Factorial Analysis of Scale of Perceived Threat from the Mentally III (SPTMI). João Pessoa (PB), Brazil, 2017 


\section{Discussion}

The objective of this second study was to gather additional evidence of factorial validity and accuracy of the SPTMI. The confirmatory factor analysis of the measurement indicated the adequacy of the proposed factor structure, the fit indexes obtained are considered to be adequate by the literature (Garson, 2012). In addition, alternative models were tested to ensure that the structure with two correlated factors was the most appropriate. As can be seen from the results, all factors presented adequate internal consistency indexes. In summary, the two-factor structure of the SPTMI has been replicated, ensuring evidence of its psychometric properties (factor validity and internal consistency).

\section{General Discussion}

In this article, two studies were presented with the objective of elaborating and demonstrating preliminary evidence of factorial validity and internal consistency of the SPTMI. In the current context of carrying out the Psychiatric Reform, it is of great relevance to study and measure the variable perception of threat from people with mental disorders, since it is related to the desire to distance oneself from people in psychological distress because they are perceived as a real threat to our physical and social integrity, thus leading to prejudice and discrimination. Pereira et al. (2010) and Nata (2011) point out that in the relationship between prejudice, discrimination and perception of threat, the feeling of threat can be understood as a predictor of the various forms of discrimination, including social exclusion, in the sense that the greater the perceived threat, the greater this discrimination will be, implying less social acceptance of people with mental disorders in society.

The final version of the scale consisted of nine items divided into two factors and presented satisfactory evidence of factorial validity and internal consistency (Clark \& Watson, 1995; Nunnally, 1991), which can be properly used to assess the perception of threat from people with mental disorders. To confirm the results, two studies were carried out, Study 1 (exploratory) showed that the scale adequately measures two factors, named dangerousness ( $\alpha=0.80$ ) and unpredictability ( $\alpha=0.75$ ); Study 2 (confirmatory) attested to the adequacy of these factors to measure the perception of threat posed by the mentally III, dangerousness $(\alpha=0.79)$ and unpredictability $(\alpha=0.74)$. Thus, the two-factor structure (Dangerousness and Unpredictability) of the scale proved to be the most adequate in the two studies carried out. The Dangerousness of the Mentally Ill dimension gathers items that describe the person with mental disorder as someone threatening and causing fear in the population. The Unpredictability dimension groups together items that involve an understanding of people with mental disorders as individuals who cannot be trusted because they can act impulsively at any time, someone who has no control over their acts and impulses. These scale factors corroborate with studies in the area and explain widespread beliefs in society about people with mental disorders, that they are dangerous and unpredictable people and, therefore, need to be excluded from society, while not adhering to the new policies of mental health care based on the Psychiatric Reform (Dias, 2015; Melo, 2017; Nee \& Witt, 2013; Sousa, Maciel, \& Medeiros, 2018).

According to Menegat (2010), the idea of deinstitutionalization of people with mental disorders brings to the discussion a worldwide problem of historical stigmatization and social exclusion of people with mental disorders, generated by psychiatric care based on a hospital-centered model and on medical hegemony and pharmacological treatment. It is known that negative representations are at the root of the processes of prejudice and social exclusion (Pereira, Pereira, \& Monteiro, 2016) and the restriction of the rights of people designated as "crazy", creating and justifying prejudiced and oppositional attitudes to the policies of inclusion, such as the resistance to the implementation of the Psychiatric Reform (Mfoafo-M'Carthy \& Huls, 2014; Neto \& Avellar, 2015; Pescolido et al., 2013; Simoni et al., 2017). 
In view of the above, it is appropriate to state that the SPTMI is a contribution to the field of studies regarding mental disorders and processes of prejudice and social exclusion, since it has shown satisfactory evidence of factorial validity and internal consistency and may be used in research that aims to assess the perception of threat from people with mental disorders, thus filling a gap in measurements on this topic, especially in the Brazilian context.In addition, this instrument can be used by professionals working in the field of mental health to assess the perception of threat to people with mental disorders in different contexts of social inclusion and its relationship with the effectiveness of the Psychiatric Reform, in order to measure prejudice anchored in the stereotypes of dangerousness and unpredictability in regards to people with mental disorders, which may contribute to the analysis of public policies in the area.

\section{Final Considerations}

Although we have made progress in the field of Psychiatric Reform and rights guaranteeing laws in our society, with institutional provisions that advocate more humane and inclusive treatments, there are still negative and stereotyped representations in regard to people with mental disorders, who are still perceived as dangerous and unpredictable, leading to an attitude of social withdrawal. Therefore, we must fight for the inclusion of people with mental disorders in our society, seeking to build a society, based on new values, new representations and new social relationships. This can contribute to overcoming stigmatization and discrimination towards people with mental disorders, seeking broader social insertions and respect for human rights and autonomy for these people.

Although the SPTMI presents itself as an adequate option to measure this construct, it is emphasized, however, that the present research is not without limitations in the studies carried out. It should be mentioned that the measure used was self-reporting and this can allow the participants' responses to be influenced by social desirability, that is, the responses can be given according to what is socially desirable. For this reason, it is suggested that researches be carried out to assess the perception of threat from people with mental disorders through implicit measures, seeking to minimize the effects of social desirability. The sample used was of convenience and consisted of university students; therefore, it is suggested that future studies be carried out using the SPTMI in experimental studies and with other samples, such as, for example, the general population and mental health professionals, in order to verify the effectiveness and stability of the measure in other samples. We emphasize that these limitations do not make the SPTMI unfeasible, given the good values achieved in the studies carried out. Furthermore, this scale can be used in correlational and experimental studies, together with attitudinal and behavioral measures in relation to mental patients, as the perception of threat measured by the SPTMI, in the dangerousness and unpredictability factors, can be used as predictors of prejudice against the person with mental disorder in today's society, which is an important component for analyzing behaviors that impact the acceptance of new mental health care policies.

\section{Acknowledgments}

This research was funded by the Coordination for the Improvement of Personnel and Higher Education (CAPES) through a scholarship granted to the first author to carry out post-doctoral studies at the Institute of Social Sciences of the University of Lisbon and linked to the MCTI/CNPq n. 01/2016, project entitled "Adherence to psychiatric reform: analysis of causal beliefs, social exclusion and prejudice against the mentally IIl". João Pessoa, Paraíba, Brazil.

\section{Contributors}

All authors contributed to the conception and design of this study, analysis and interpretation of data, discussion of results, review, and approval of the final version of the manuscript. 


\section{References}

American Educational Research Association, American Psychological Association, \& National Council on Measurement in Education. (2014). Standards for educational and psychological testing. Washington: Author.

Amorim, R. G., \& Lavrador, M. C. C. (2017). A perspectiva da produção de cuidado pelos trabalhadores de saúde mental. Psicologia: Ciência e Profissão, 37(2), 273-288. http://dx.doi.org/10.1590/1982-370300332015

Angermeyer, M. C., Matschinger, H., Carta, M. G., \& Schomerus, G. (2014). Changes in the perception of mental illness stigma in Germany over the last two decades. European Psychiatry, 29(6), 390-395. http://dx.doi.org/10.1016/j. eurpsy.2013.10.004

Bardin, L. (2002). Análise de conteúdo. Lisboa: Edições 70.

Barros, C. M. D. L., Torres, A. R. R., \& Pereira, C. R. (2017). Atitudes de estudantes de medicina face ao "Mais Médicos" revela favorecimento endogrupal. Psico, 48(1), 12-20. http://dx.doi.org/10.15448/1980-8623.2017.1.23871

Byrne, B. M. (2010). Structural equation modeling with AMOS: basic concepts, applications, and programming (2nd ed.). New York: Routledge.

Clark, L. A., \& Watson, D. (1995). Constructing validity: basic issues in objective scale development. Psychological Assessment, 7(3), 309-319. http://dx.doi.org/10.1037/1040-3590.7.3.309

Damásio, B. F. (2012). Uso da análise fatorial exploratória em psicologia. Avaliação Psicológica, 11 (2), 213-228. Recuperado de http://pepsic.bvsalud.org/scielo.php?script=sci_arttext\&pid=S1677-04712012000200007

Dias, F. X. (2015). Representações sociais da doença mental construídas por profissionais da saúde (Dissertação de mestrado não-publicada). Faculdade de Filosofia, Ciências e Letras de Ribeirão Preto.

Evans-Lacko, S., Henderson, C., \& Thornicroft, G. (2013). Public knowledge, attitudes and behaviour regarding people with mental illness in England 2009-2012. The British Journal of Psychiatry Supplement, 202(55), 51-57. http://dx. doi. org/10.1192/bjp.bp.112.112979

Foucault, M. (2012). História da loucura na Idade Clássica. São Paulo: Perspectiva (Originalmente publicado em 1978).

Fukuda, C. C., Penso, M. A., Amparo, D. M., Almeida, B. C., \& Morais, C. A. (2016). Mental health of young Brazilians: barriers to professional help-seeking. Estudos de Psicologia (Campinas), 33(2), 355-365. http://dx.doi.org/10.1590/198 2-02752016000200017

Garson, G. D. (2012). Structural equation modeling. Asheboro: Statistical Associates Publishers.

Horn, J. L. (1965). A rationale and technique for estimating the number of factors in factor analysis. Psychometrika, 30(1), 179-185. http://dx.doi.org/10.1007/BF02289447

Jodelet, D. (2005). Loucuras e representações sociais. Rio de Janeiro: Vozes.

Loureiro, L. M. J., Dias, C. A. A., \& Aragão, R. O. (2008). Crenças e atitudes acerca das doenças e dos doentes mentais: contributos para o estudo das representações sociais da loucura. Revista de Enfermagem Referência, 2(8), 33-44. Recuperado de https://www.redalyc.org/articulo.oa?id=388239955003

Maciel, S. C., Pereira, C. R., Lima, T. J. S., \& Souza, L. E. C. (2015). Desenvolvimento e validação da Escala de Crenças sobre a Doença Mental. Psicologia: Reflexão e Crítica, 28(3), 463-473. http://dx.doi.org/10.1590/1678-7153.201528305

Matsunaga, M. (2010). How to factor-analyze your data right: do's, don't's, and how-to's. International Journal of Psychology Research, 3(1), 97-110. Retrieved from http://www.redalyc.org/articulo.oa?id=299023509007

Melo, J. R. F. (2017). Preconceito flagrante e sutil frente à esquizofrenia: explicações com base em crenças causais e estereótipos (Tese de doutorado não-publicada). Universidade Federal da Paraíba.

Menegat, D. R. (2010). A desinstitucionalização do portador de doença mental e a reforma psiquiátrica brasileira. Revista do Ministério Público do RS, 66, 33-64. Recuperado de http://www.amprs.org.br/arquivos/revista_artigo/ arquivo_1285763100.pdf

Mfoafo-M'Carthy, M., \& Huls, S. (2014). Human rights violations and mental illness: implications for engagement and adherence. Sage Open, 4, 1-18. http://dx.doi.org/10.1177/2158244014526209

Monterrubio, C. (2015). The impact of spring break behavior: an integrated threat theory analysis of residents' prejudice. Tourism Management, 54(2016), 418-427. Retrieved from https://www.sciencedirect.com/science/article/ pii/S026151771530056X

Nata, G. (2011). Diferença cultural e democracia: identidade, cidadania e tolerância na relação entre maioria e minorias (Tese de doutorado não-publicada). Universidade do Porto.

Nee, C., \& Witt, C. (2013). Public perceptions of risk in criminality: the effects of mental illness and social disadvantage. Psychiatry Research, 209(3), 675-683. http://dx.doi.org/10.1016/j.psychres.2013.02.013 
Neto, P. M. R., \& Avellar, L. Z. (2015). Identidade social e desinstitucionalização: um estudo sobre uma localidade que recebe residências terapêuticas no Brasil. Revista Saúde e Sociedade, 24(1), 204-216. http://dx.doi.org/10.1590/ S0104-12902015000100016

Nunnally, J. C. (1991). Teoría psicométrica. Cidade do México: Trillas.

Pacico, J. C., Hutz, C. S., Schneider, A. M. A., \& Bandeira, D. R. (2018). Validade. In C. S. Hutz, D. R. Bandeira \& C. M. Trentini (Org.), Psicometria (pp.71-83). Porto Alegre: Artmed.

Pereira, A., Pereira, C. R., \& Monteiro, M. B. (2016). Normative pressure to reduce prejudice against homosexuals: the buffering role of beliefs about the nature of homosexuality. Personality and Individual Differences, 96, 88-99. http:// dx.doi.org/10.1016/j.paid.2016.02.042

Pereira, C. R., \& Souza, L. E. C. (2016). Fatores legitimadores da discriminação: uma revisão teórica. Psicologia: Teoria e Pesquisa, 32, 1-10. http://dx.doi.org/10.1590/0102-3772e322222

Pereira, C. R., \& Vala, J. (2011). A legitimação da discriminação em diferentes contextos normativos. In E. M. Techio \& M. E. O. Lima (Eds.), Cultura e produção das diferenças: estereótipos e preconceito no Brasil, Espanha e Portugal (pp.363-404). Brasília: Technopolitik.

Pereira, C. R., Álvaro, J. L., \& Vala, J. (2018). The ego-defensive role of legitimacy: how threat-based justifications protect the self-esteem of discriminators. Persomality and Social Psychology Bulletin, 44(10), 1473-1486. http://dx.doi. org/10.1177/0146167218771007

Pereira, C., Vala, J., \& Costa-Lopes, R. (2010). From prejudice to discrimination: the legitimizing role of perceived threat in discrimination against immigrants. European Journal of Social Psychology, 40, 1231-1250. http://dx.doi.org/10.1002/ ejsp.718

Pereira, C., Vala, J., \& Leyens, J. -P. (2009). From infra-humanization to discrimination: the mediation of symbolic threat needs egalitarian norms. Journal of Experimental Social Psychology, 45, 336-344. http://dx.doi.org/10.1016/j. jesp.2008.10.010

Pescosolido, B. A., Medina, T. R., Martin, J. K., \& Long, K. S. (2013). The "backbone" of stigma: identifying the global core of public prejudice associated with mental illness. American Journal of Public Health, 103(5), 853-860. http:// dx.doi.org/10.2105/AJPH.2012.301147

Reppold, C., Gurgel, L., \& Hutz, C. (2014). O processo de construção de escalas psicométricas. Revista Avaliação Psicológica, 13(2), 307-310. Recuperado de http://pepsic.bvsalud.org/scielo.php?pid=S167704712014000200018\&script=sci_ abstract\&tlng=es

Rosa, E. (2003). Do adoecimento psíquico à subjetividade que sofre: a importância da leitura sócio-histórica. In Conselho Federal de Psicologia (Org.), Loucura, ética e política: escritos militantes (pp.211-219). São Paulo: Casa do Psicólogo.

Schlier, B., Schmick, S., \& Lincoln, T. M. (2014). No matter of etiology: biogenetic, psychosocial and vulnerability-stress causal explanations fail to improve attitudes towards schizophrenia. Psychiatry Research, 215, 753-759. http://dx.doi. org/10.1016/j.psychres.2013.12.056

Serafim, R. C. N. S., Bú, E. A., Maciel, S. C., Santiago, T. R. S., \& Alexandre, M. E. S. (2017). Representações sociais da reforma psiquiátrica e doença mental em universitários brasileiros. Psicologia, Saúde \& Doenças, 18(1), $221-233$. http://dx.doi.org/10.15309/17psd180118

Shimoguiri, A. F. D. T., \& Costa-Rosa, A. (2017). A prática de atenção à saúde nos estabelecimentos psicossociais: efeitos do modo capitalista de produção. Psicologia USP, 28(3), 389-395. http://dx.doi.org/10.1590/0103-656420160123

Simoni, D., Lazarini, W. S., \& Madureira, R. (2017). Saúde mental e o processo de gestão de serviços residenciais terapêuticos. Revista Brasileira de Pesquisa em Saúde, 19(1), 101-107. Recuperado de http://www.periodicos.ufes. br/RBPS/article/viewFile/17724/12150

Sousa, P. F., Maciel, S. C., \& Medeiros, K. T. (2018). Psychosocial x biomedical paradigm: where is the social representation anchored in psychic suffering? Temas em Psicologia, 26(2), 883-895. http://dx.doi.org/10.9788/tp2018.2-13pt

Sousa, S., Marques, A., Curral, R., \& Queirós, C. (2012). Stigmatizing attitudes in relatives of people with schizophrenia: a study using the Attribution Questionnaire AQ-27. Trends in Psychiatry and Psychotherapy, 34(4), 186-197. http:// dx.doi.org/10.1590/S2237-60892012000400004

Stephan, W. G., \& Stephan, C.W. (2000). An integrated threat theory of prejudice. In S. Oskamp (Ed.), Reducing prejudice and discrimination (pp.23-46). Hillsdale: Lawrence Erlbaum.

Received: October 8, 2019

Final version: March 4, 2020

Approved: April 13, 2020 